\title{
Local Language, Bahasa Indonesia, or Foreign Language?
}

\author{
Aam Alamsyah \\ English Applied Linguistics Program \\ Atma Jaya Catholic University of Indonesia \\ CIDES Indonesia \\ Jakarta, Indonesia \\ alamsyah_expert@yahoo.com
}

\begin{abstract}
The number of local languages in Indonesia has significantly decreased due to the declining number of its speakers. In fact, local languages have long been considered as one of the identities of those living across archipelago. The present study aimed at analyzing the education stakeholders' attitudes toward local language, bahasa Indonesia, and English in order to investigate the role of each language, and the possible survivability in Indonesian society. This study was a case study which involved very limited participants (two headmasters, two parents, and two students) within a specific time frame. The instrument employed was a semi-structured interview. The language used in the interview was the respondents' language (bahasa Indonesia) in order that they could freely express what they had in mind about the three languages above. Despite the respondents' positive attitudes toward their local languages, bahasa, and English, the demand of the parents to make their children more mobile and more skillful has made the school management provide more foreign languages instead of local languages. The lack of qualified teachers, and obsolete teaching materials were also identified as the most gargantuan problems that should be overcome. Some suggestions were offered to tackle the problems.
\end{abstract}

Keywords-Local language; Bahasa Indonesian; foreign language

\section{INTRODUCTION}

Indonesia is undoubtedly a country which has various cultures; thus resulting in the variety of ways of thinking, and behaving [1]. The variety of cultures in Indonesia is believed as one of the attributes of Indonesia as a culturally diverse nation[2]. The existence of language as one of the inseparable elements of culture [3], [4] indicates that the attempt to preserve culture should actually be started from local languages with which such cultural values can be shared or communicated among the community members.

Ironically, whatsoever, local languages are given very little portion in Indonesian education context [5]. Scholars suggested that there were some influential factors which might have undermined local languages in Indonesian society such as the lack of government's support [6], the demand of education stakeholders [7], as well as the perceived benefits of foreign language learning [8], [9], [10], [11].
The present study aimed at analyzing those involved in pedagogical context (headmasters, parents, and students) and their attitudes toward their own local language, bahasa Indonesia, and foreign language (i.e. English).

So far, studies on people's attitudes toward language merely focused on foreign language [12], [13], [10]. Studies which analyzed people's attitudes toward their own local language, bahasa Indonesia, and foreign language simultaneously are barren. In fact, scholars believed that preserving local languages was important due to the perceived benefits such as supporting the people's adaptability, being the shared attribute of those living in the same region, contributing to the sum of human knowledge, and becoming an interestingattribute of the people [9], [14].

Analyzing Indonesian people's attitude toward local language, bahasa Indonesia, and foreign language simultaneously is therefore important in that it could possibly describe the possible survivability or the death of the above languages directly from the speakers. Just as what the noted scholar has long postulated that that language will demise when there is no one who is willing to speak it [15].

The research questions were formulated as the followings:

1) How do the respondents describe their attitudes toward their own local language, Bahasa Indonesia, and Foreign language?

2) How do the respondents describe some factors perceived as determinants toward their language attitudes?

Since the term attitude(s) is discussed by numerous scholars of different fields (Social psychology, and Sociolinguistics), the present study adopted attitudes as "a hypothetical construct used to explain the direction and persistence of human behavior"'[16], thus making it a sociolinguistic study. The term "determinants" were also taken from the same scholar referring to some influential factors which can possibly affect people's language attitudes [16].

The term foreign or international language referred to English due to the consideration that the English teaching in Indonesia belongs to EFL context [17]. The choice of English as the focus in this study was also due to the consideration that 
the datarelated to the English teaching (EFL) were more accessible compared with the other languages.

The present study was conducted in pedagogical contexts, thus the participants recruited were the ones involved in teaching and learning process such as headmasters, parents, and students of two different national plus schools (formerly called as international schools).

There was limited number of participants ( 2 headmasters, 2 parents, and 2 students) who took part in this study. Any attempt to generalize the result of this study should consider the background or the context of the institutions or other relevant factors.

\section{A. Local language learning, bahasa Indonesia, or Foreign languages?}

Undeniably, the trend to learn foreign or international languages in Indonesia is significantly increasing [18]. The above trend, nonetheless, has aroused concerns among the scholars since they strongly believe that these internationally recognized languages might undermine the local languages, [15], [5].

In Indonesian context, the dominant use of English, for instance, has also been considered as one of the possible causes of the declining use of Bahasa Indonesia and other local languages[5]or at the very least, as the factor which has partially influenced "the language choice" of many Indonesians[19].

Despite bickering over the possible culpritswhich might have undermined local languages [20],[5], [19], most scholars believed that it was important to support the existence of local languages in order to prevent language shift or language loss[15] [21] [14]. Scholars believed that language shift might happen when the speakers thought that they would have more reward when using another language[16].

\section{B. Language as part of culture}

The existence of language as part of cultural elements has been theorized by some scholars. Generally, culture consists of five elements: firstly, belief deemed as a conviction toward an entity or object and mostly gained through observation, logic, tradition, other people's opinion, or faith; secondly, technology considered as any repeated operation that people use to manipulate their environment to achieve some practical goals; thirdly, norms considered as the guidelines to direct and control humans due to the absence of instinct in humans; fourthly, values which are deemed as general convictions about what is good or bad, right or wrong, appropriate or inappropriate; lastly, language which is considered as the system of symbolic communication using words, having sound patterns, and standardized meaning[3].

Unlike the first paradigm, the second view categorized culture into fewer elements: language, norms, values, and sanctions. The second paradigm suggested that language was the first element allowing each cultural group member to perform "daily exchange" among each other [4].
C. The mushrooming of private educational institutions adopting foreign or international language as their teaching instruction

It is indeed hard to deny that there are getting more schools in Indonesia which claim to be modern in their curricula by simply allocating foreign language teaching instructions in their teaching and learning process [22].Scholars suggested that the urgency of learning foreign or international language was basically triggered by the intensification of worldwide social relation and interdependence popularly called as globalization [23].

As one of the most affected sectors, education institutions are forced to prepare their students so that they will be able to actively participate in the new era [24]. The introduction of foreign language which is sometimes touted as international or even global language in pedagogical context is undoubtedly to cater the above objective [25].

However, since scholars believed that learning process constitutes a relatively permanent change of the learners' behavior due to the reinforced practices [26], [27], the learning process conducted in different language other than the students' native language will inevitably create a different experience into their children's mind and might lead to different attitudinal direction.

One of the noted researchers, for instance, has long warned that learning second language or foreign language in early age can adversely affect the learners' first language. She firmly argued that there was a great possibility for children to forfeit and lose their primary languages when children were exposed to foreign language (i.e., English) in such young age [28].

In fact, language is not only a tool for communication and knowledge but might also serve as "a fundamental attribute of cultural identity and empowerment either for an individual or for the group". Therefore respecting the languages of persons belonging to different linguistic communities was essential to peaceful cohabitation [14].

Empirically, children were proven to learn best in their mother tongue as "a prelude to and complement of bilingual and multi-lingual education". Research also indicated that "six to eight years of education in a language are necessary" to develop the level of literacy and verbal proficiency required for academic achievement in secondary school [14].

Psychologically, language is also important to support the children's growth, due to the fact that the first language that most children acquire and communicate naturally among the family members is actually local languages (language that children and parents use in their daily communication in early age), thus making them inseparable to the children's development [26].

\section{RESEARCH METHOD}

Since this study was conducted in a limited number of participants, the researcher employed a case study. Although the nature of the term can also be considered as case studies 
due to the fact that the respondents ( 2 headmasters, 2 parents, and 2 students learning in national plus schools) might portray typically different cases [29], [30], [31].

A case study is considered as an in-depth exploration of a bounded system (e.g., an activity, event, process, or individuals) which was based on extensive data collection[31]. The term "bounded" usually refers to the case which is separated out for research in terms of time, place, or some physical boundaries"'[31].

The data were taken in June 2016 when the researcher visited two national plus schools to interview the headmasters. The next day, the interview was conducted to the students' parents accompanying their children at the schools. Lastly, the students of different parents (the students and parents interviewed were different and did not have familial relationship to enable the researcher to have more varied data) were interviewed consecutively.

The instrument used for this study was a semi-structured interview so that the researcher could possibly elicit more information needed besides helping participants to freely express their idea toward the above topics. The interviews were all conducted in L1 (bahasa Indonesia) to enable the interviewees to provide more elaborate responses to the researcher.

Scholars believe that the use of the participants' mother tongue (i.e. bahasa Indonesia) for the sake of eliciting their verbal responses is the effort to guarantee that the participants could express their views freely [29].

After the interview (recorded for the sake of maintaining the data), the oral responses were transcribed in order that the researcher could analyze the important themes of the text. The researcher adopted the coding process for qualitative analysis [31]. The model was further simplified in order to fit this study:

1. Initially read through the text data.

2. Divide the text into segments of information.

3. Label the segments with code.

4. Reduce overlap and redundancy of codes

5. Collapse codes into themes

Generally, themes could be called categories which constitute similar codes aggregated together to form a major idea in the database [31].

\section{FINDINGS AND ANALYSIS}

The following is the section presented to discuss the findings based on the two research questions formulated before. In order to answer the research questions, the interview extracts were recorded. Further, the themes were elicited from the respondents' verbal responses (two headmaster, two parents, and two students). The followings are the English translated extracts.

1) How do the respondents describe their attitudes toward their own local language, bahasa Indonesia, and foreign language?
Table 1. Headmasters

\begin{tabular}{|l|l|}
\hline \multicolumn{2}{|c|}{ Respondents: Headmasters (n=2) } \\
\hline \multicolumn{1}{|c|}{ Themes } & \multicolumn{1}{|c|}{ Extracts } \\
\hline $\begin{array}{l}\text { Local language is } \\
\text { Ine identity of the }\end{array}$ & $\begin{array}{l}\text { I believe that local language is } \\
\text { important in that it can become the } \\
\text { identity of those living across different } \\
\text { regions in Indonesia. }\end{array}$ \\
\hline $\begin{array}{l}\text { bahasa Indonesia is } \\
\text { important to unite } \\
\text { Indonesian people }\end{array}$ & $\begin{array}{l}\text { We consider that bahasa is important to } \\
\text { unite all Indonesians. }\end{array}$ \\
\hline $\begin{array}{l}\text { Foreign language is } \\
\text { important to prepare } \\
\text { the students to be } \\
\text { world citizen }\end{array}$ & $\begin{array}{l}\text { We believe that foreign language or } \\
\text { even international language is } \\
\text { important to equip our children to be } \\
\text { the world citizen. }\end{array}$ \\
\hline
\end{tabular}

Based on the table 1, it could be found that basically both of the headmasters of the schools recognized the important role of local language as a means for representing Indonesian locals who live across archipelago. The statements above also indicated that cognitively the headmaster had positive attitudes toward local language.

In terms of bahasa, both of the headmasters also indicated their positive attitudes, while confirming that Indonesian language is considered as a means for uniting the nation. Lastly, both of the headmasters indicated positive attitude toward the roles of foreign or international language which they believed to be useful in supporting their mission to create the world class citizen.

Table 2. Parents

\begin{tabular}{|l|l|}
\hline \multicolumn{2}{|c|}{ Respondents: Parents $(\mathrm{n}=2)$} \\
\hline \multicolumn{1}{|c|}{ Themes } & \multicolumn{1}{c|}{ Extracts } \\
\hline $\begin{array}{l}\text { Local language is } \\
\text { our pride }\end{array}$ & $\begin{array}{l}\text { As a person who comes from remote } \\
\text { area in Indonesia, I am proud of my } \\
\text { local language. }\end{array}$ \\
\hline $\begin{array}{l}\text { Bahasa Indonesia is } \\
\text { a source of pride }\end{array}$ & $\begin{array}{l}\text { We use Bahasa at home as an } \\
\text { indication that we are proud of being } \\
\text { Indonesian }\end{array}$ \\
\hline $\begin{array}{l}\text { Foreign language } \\
\text { enables their } \\
\text { children to achieve } \\
\text { their career } \\
\text { objective }\end{array}$ & $\begin{array}{l}\text { Why shouldn't we learn other } \\
\text { languages? In fact we have spent a lot } \\
\text { for this program. I am sure that the } \\
\text { choice of my children to learn foreign } \\
\text { language is right because he wants to } \\
\text { pursue higher career objective in the } \\
\text { future. }\end{array}$ \\
\hline
\end{tabular}

Similarly, positive attitudes were also shown in the parents' interview, in that they still strongly believed in the importance of local language for Indonesian locals. The existence of bahasa Indonesia was also considered very important for them. Lastly, the existence of foreign languages was also seen as positive factors enabling their children to have better career. 
Table 3. Students

\begin{tabular}{|l|l|}
\hline \multicolumn{2}{|c|}{ Respondents: Students (n=2) } \\
\hline \multicolumn{1}{|c|}{ Themes } & \multicolumn{1}{c|}{ Extracts } \\
Indonesian identity & $\begin{array}{l}\text { Although I don't use it, but I am proud } \\
\text { of watching movie with my local } \\
\text { language, for me local language is } \\
\text { Indonesian identity. }\end{array}$ \\
\hline $\begin{array}{l}\text { Bahasa Indonesia is } \\
\text { the daily language at } \\
\text { home }\end{array}$ & $\begin{array}{l}\text { My parents, and I speak Bahasa at } \\
\text { home, I also speak Bahasa because I } \\
\text { believe that Bahasa Indonesia is } \\
\text { important. }\end{array}$ \\
\hline $\begin{array}{l}\text { Foreign language is } \\
\text { important to pass } \\
\text { college entrance }\end{array}$ & $\begin{array}{l}\text { May be I like it, or may be because } \\
\text { English is important for my future, you } \\
\text { know that attending college means a } \\
\text { good English and being able to pass the } \\
\text { interview. So, how can I have a chance } \\
\text { to study overseas if my English is bad? }\end{array}$ \\
\hline
\end{tabular}

The students, alike, showed their positive attitudes toward their local languages. They indicated strong belief that their local language was an inseparable identity for them. With regard to the role of Indonesian language, the students also indicated similarly positive attitudes toward their national language.

Lastly, the existence of foreign language or international language was also seen as a positive entity with which they could finally reach their dream to study overseas or pursue a good career.

2) How do the respondents describe some factors perceived as determinants toward their language attitudes?

Table 4. Headmasters

\begin{tabular}{|l|l|}
\hline \multicolumn{2}{|c|}{ Respondents: Headmasters (n=2) } \\
\hline \multicolumn{1}{|c|}{ Themes } & \multicolumn{1}{c|}{ Extracts } \\
globalization era & $\begin{array}{l}\text { We have policy to prepare our students to } \\
\text { compete in a global world, thus making us } \\
\text { work hard to achieve this aim that } \\
\text { includes preparing the students with the } \\
\text { most popularly spoken languages. }\end{array}$ \\
\hline $\begin{array}{l}\text { The demand of } \\
\text { stakeholders }\end{array}$ & $\begin{array}{l}\text { as a privately funded school, we cannot } \\
\text { resist the demands of the students' parents } \\
\text { who have trusted their children to study } \\
\text { here, some of those are wishing to send } \\
\text { their children overseas }\end{array}$ \\
\hline $\begin{array}{l}\text { The lack of teachers } \\
\text { and the other }\end{array}$ & $\begin{array}{l}\text { We must also prepare many things for } \\
\text { learning supports } \\
\text { the teaching process, and so on. And } \\
\text { remember, not many local language } \\
\text { teachers who are willing to be paid on } \\
\text { part-time basis too. }\end{array}$ \\
\hline $\begin{array}{l}\text { The students might } \\
\text { not be interested in } \\
\text { learning local } \\
\text { language }\end{array}$ & $\begin{array}{l}\text { Do you know that the students who might } \\
\text { learn local language program are those } \\
\text { who have been overwhelmed by lots of } \\
\text { extras so I am not sure that they are } \\
\text { willing to participate in the local language } \\
\text { program if the program is not interesting. }\end{array}$ \\
\hline
\end{tabular}

From the Table 4 we can find that the head masters were convinced that the existence of local languages were basically important. However, the problems lie in the implementation of the teaching of local languages ranging from the teaching material, syllabus, teaching method, and also the teacher who might be willing to be recruited on part-time basis, due to the consideration that the sessions offered to students will be limited.

Scholars have long postulated that there are several factors which might contribute to the success or failure of the language learning such as teaching method, teaching material/media, the role of teacher, and so forth. Such multifaceted quandary indicated the importance of pedagogical supports postulated by some scholars such as the need to have good quality teacher, interesting media or teaching materials to support the students' learning process [32], [33], [12], [34], [35].

Lastly, factors such as motivation and attitudes are also important, thus the teacher must also be the ones who are able to identify the students' unique characteristics and be willing to appreciate the students' differences [36], [37].

Table 5. Parents

\begin{tabular}{|l|l|}
\hline \multicolumn{2}{|c|}{ Respondents: Parents $(\mathrm{n}=2)$} \\
\hline \multicolumn{1}{|c|}{ Themes } & \multicolumn{1}{c|}{ Extracts } \\
\hline $\begin{array}{l}\text { The demand of } \\
\text { being able to pursue } \\
\text { a better career }\end{array}$ & $\begin{array}{l}\text { Certainly, we are supposed to learn more } \\
\text { international languages, since the jobs at } \\
\text { the moment require the people to be } \\
\text { more mobile }\end{array}$ \\
\hline $\begin{array}{l}\text { Too many activities } \\
\text { have sapped up their } \\
\text { children's energy }\end{array}$ & $\begin{array}{l}\text { My children have been very exhausted } \\
\text { with lots of activities, thus other } \\
\text { activities might make him fatigued }\end{array}$ \\
\hline $\begin{array}{l}\text { Not many students } \\
\text { interested in local } \\
\text { languages }\end{array}$ & $\begin{array}{l}\text { It is certainly understandable if the } \\
\text { students are not really interested in the } \\
\text { local language training since the teaching } \\
\text { is too much emphasizing local values, } \\
\text { instead of being contextualized with } \\
\text { modern sphere or situation }\end{array}$ \\
\hline
\end{tabular}

From Table 5, it could be found that the parents were the ones that made their children and school focus on foreign or international languages, instead of having local language programs.

The need to prepare their children's future has made the school management prioritize international languages to be learned by their children. The conviction on the obsolete teaching method adopted in local language learning has also strengthened the need for major reform in local language teaching paradigm adopted at present time. 
Table 6. Students

\begin{tabular}{|l|l|}
\hline \multicolumn{2}{|c|}{ Respondents: Students (n=2) } \\
\hline \multicolumn{1}{|c|}{ Themes } & \multicolumn{1}{c|}{ Extracts } \\
\hline $\begin{array}{l}\text { Students' focus on } \\
\text { being admitted in } \\
\text { prestigious colleges } \\
\text { at home/abroad. }\end{array}$ & $\begin{array}{l}\text { I have to focus to my soft skills or } \\
\text { whatever skill which enable me to have } \\
\text { more competitive gains compared with } \\
\text { others, especially in order to be } \\
\text { accepted in college abroad. }\end{array}$ \\
\hline $\begin{array}{l}\text { The demand for } \\
\text { securing/having a } \\
\text { good job. }\end{array}$ & $\begin{array}{l}\text { I need to prepare to find a job, since my } \\
\text { parents don't have enough money to } \\
\text { support my future life. }\end{array}$ \\
\hline $\begin{array}{l}\text { The exhaustive } \\
\text { programs prevent } \\
\text { the students to learn } \\
\text { local languages }\end{array}$ & $\begin{array}{l}\text { I am too much tired with my work at } \\
\text { school. I don't even have time to play } \\
\text { sometimes, so despite its importance, I } \\
\text { might be unable to attend the program. }\end{array}$ \\
\hline
\end{tabular}

Despite having positive attitudes toward local languages, students' workload in their academic life makes them unable to focus on other aspects (i.e. local languages). Besides, higher academic grade in foreign languages was also considered mandatory for them to pursue academic qualification overseas (one of them was dreaming for having college experience overseas, while the rest claimed that his English was important to make him become a more competitive jobseeker).

\section{CONCLUSION}

Based on the findings, it could be concluded that basically all of the respondents (headmasters, parents, and students) still indicated positive attitudes toward their local languages which they considered important to represent their identities as well as a means for uniting their diversity.

Additionally, it was also found that there were lots of problems faced by local languages,particularly in terms of pedagogical aspects such as the lack of qualified teachers, obsolete teaching materials, and more enjoyable teaching method.

In micro level, it was found that the demand of the school stakeholders (parents) was proven very significant in making the school management provide their students with more foreign languages. On the other hand, in the macro level, the need to survive in globalization was the most significant drive.

The need to preserve local language is important due to the connection of language with culture[3] [4]. The missing role of culture as a collective programing [38] will not only make people forfeit the way they behave and lead their life [1], but also eliminate the sense of cohesiveness of being the member of the society among them [14].

In order to prevent the loss of the local languages, the government should reward those involved in disseminating and researching local languages well so that they would be more motivated to conduct their duties [39].

Excessive exposure on foreign languages experienced by the students (especially the younger ones) in their learning process will probably affect their first language [28] due to the conviction that this learning process will generally entail a change in the students' attitude, or behavior [1], [26], [27], thus resulting in the potential change of their language attitude in the future.
The analysis of the students' language attitude [16], [40] in a more comprehensive manner including the large number of participants involved in educational context (e.g., teachers, headmasters, students, and students' parents, etc.) is critical so that we could find the more valid and reliable data on how the students' attitudes toward their own local languages might change and affect their behavior to learn them in the future [41], [16].

\section{ACKNOWLEDGMENT}

The author wishes to thank Atma Jaya Catholic University of Indonesia and Mr. Rudi Wahyono of CIDES Indonesia for the grant provided to him to participate in international seminar"ICIGR" 2017.

\section{REFERENCES}

[1] H. D. Brown, The principles of language learning and teaching. New Jersey: Prentice Hall Regent, 2000.

[2] LIPI. (2015, Dec.) LIPI. [Online]. http://lipi.go.id/berita/single/BahasaDaerah-Tergerus-Zaman/10436

[3] C. B. Doob, Sociology: An introduction. New York: Rinehart and Winston, 1985.

[4] R. T Schaefer, Sociology. New York: McGraw-Hill, 2011.

[5] H. Coleman, "The English language as naga in Indonesia," Academia, 2016.

[6] A. Alwasilah. (2013, June) The Jakarta Post. [Online] http://www.thejakartapost.com/news/2013/06/15/unlocking-indonesianlanguage-policy.html

[7] L. Hadisantosa, "Insight from Indonesia," in Learning through English Policies, Challenges, and Prospects: Insight From East Asia. Malaysia: British Council, 2010, pp. 24-46. [Online]. http://.teachingenglish.org.uk/sites/teacheng/files/publication_1 learning_through_english.pdf

[8] I. F. Chung. (2006) University of Warwick. [Online]. http://go.warwick.uk/wrap/2449

[9] C. Baker, Foundation of Bilingual Education and Bilingualism. Oxon: Multilingual Matters, 2011.

[10] R. Novianti, "Comparing students' attitudes toward English language in an Indonesian state high school," Asean Journal of Education, pp. 203$219,2015$.

[11] H. Y Choi and W. H. Lee, "Current trends and issues in English language education in Asia," THE JOURNAL OF ASIA TEFL, pp. 1-34, 2008.

[12] H Cahyani and B Cahyono, "Teachers' attitudes and technology use in Indonesian EFL classrooms," TEFLIN Journal, pp. 130-145, 2012.

[13] S, E. Djahimo, "The attitudes of teachers and students of EFL classes toward English teaching and learning using games and pictures in rural and disadvantaged schools in Indonesia: A case study," ASIAN EFL, pp. 65-89, 2015.

[14] J. Ball, "Enhancing learning of children from diverse language backgrounds: Mother tongue-based bilingual or multi lingual education in the early years.," France, 2011. [Online]. http://unesdoc.unesco.org/images/0021/002122/212270e.pdf

[15] D. Crystal, Language death. Cambridge: Cambridge University Press, 2000.

[16] C. Baker, Attitudes and language. Clevedon: Multilingual Matters, 1992.

[17] U. Sulistyo, "Learning English as a foreign language in Indonesian university: A study of non-English department students' preferred activities inside and outside the classroom," IJET, pp. 1-26, 2016.

[18] L. N. Harwati, "World Englishes: Threat or opportunity for Indonesians? ," Sino-US English Teaching, pp. 872-877, 2012. 
[19] A Cohn and M. Ravindranath, "Local languages in Indonesia: Language maintenance or language shift?," Linguistik Indonesia, pp. 131-148, 2014.

[20] H. Coleman, "Teaching other subjects through English in three Asian nations: A review," 2009.

[21] S. Bax, "Researching English bilingual education in Thailand, Indonesia, and South Korea," Malaysia, 2010.

[22] S.C. Djonhar, "An Indonesian child learning sentence construction," Journal of ELT Research, pp. 91-101, 2016.

[23] A. Giddens, Sociology. Cambridge: Polity, 2001.

[24] S Marginson and I Ordorika, "'El central volumen de la fuerza": Global hegemony in higher education and research," in Knowledge Matters: The Public Mission of The Research University. New York: Columbia University, 2011, pp. 67-129.

[25] D. Crystal, English as a global language. New York: Cambridge University Press, 1997.

[26] R. Slavin, Educational Psychology. New York: Pearson, 2009.

[27] D.H. Schunk, Learning theories: An educational perspective. Boston, MA: Pearson, 2012.

[28] W. Fillmore, "When learning a second language means losing the first," Early Childhood Research Quarterly, pp. 323-346, 1991.

[29] S. P. Astuti. (2015, January) Teacher's and students' perceptions of motivational strategies in an Indonesian high school context.

[30] J. R Frankel and N. E. Wallen, How to design and evaluate reesarch in education. New York: Pearson, 2006.

[31] J Creswell, Educational Research: Planning, Conducting, and Evaluating Qualitative and Quantitative Research. New Jersey: Pearson, 2008.

[32] M. Brinton, "Language teaching media," in Teaching English as Second or Foreign Language. Boston, MA: Heinle \& Heinle, 2001, pp. 459-476.

[33] J. C Richards, The role of textbooks in a language program. Cambridge: Cambridge University Press., 2001.

[34] B Tomlinson, "The importance of materials development for language learning," in Issues in Materials Development. Rotterdam: Sense Publishers, 2016, pp. 1-9.

[35] H. D. Brown, Teaching by principles: An interactive approach to language pedagogy. New Jersey: Pearson, 2001.

[36] K Johnson, Introduction to foreign language learning and teaching. Harlow : Pearson. , 2008.

[37] M Lightbown and N Spada, How languages are learned. Oxford. : Oxford University Press. , 2013.

[38] G. Hofstede, "Dimensionalizing cultures: The Hofstede model in context ," Online Readings in Psychology and Culture, pp. 1-26, 2011.

[39] A Alamsyah, "“UMR" for Indonesian lecturer: A documentary research on Indonesian lecturer remuneration system," in In Search of Key Drivers of Indonesian Empowerment. Jakarta: UNIKA ATMAJAYA, 2017, pp. 1-12.

[40] P. Garrett, Attitudes to language. Cambridge: Cambridge University Press, 2010.

[41] R.H. Fazio, "How do attitudes guide behavior? ," in Handbook of Motivation and Cognition: Foundations of Social Behavior. New York : Guilford Press., 1986, pp. 204-243. 